\title{
Three new species of the genus Tanidromites (Decapoda: Brachyura: Tanidromitidae) from the Late Jurassic (Oxfordian) of Poland
}

\author{
Natalia Starzyk
}

\begin{abstract}
Representatives of Tanidromites are very common brachyurans in Oxfordian localities of southern Poland. There were four species, known before from the literature, recorded from these localities and one new. Herein three other new species are described: T. longinosa, T. schweitzerae, and T. wysokaensis. These species can be distinguished by repetitive characters of the anterior part of the carapace. Flattened augenrest was a feature characteristic for this genus before $T$. alexandrae Starzyk, 2015 was described. Tanidromites schweitzerae n. sp., described herein, is the second species of the genus with an elevated orbital margin. This species differs from others in having only the suborbital margin elevated. These new characters widen the pattern of the genus and make it more various, and might be related with the environmental changes. A key to all 14 species of Tanidromites is provided.
\end{abstract}

Natalia Starzyk. Institute of Systematics and Evolution of Animals, Polish Academy of Sciences; ul. Sławkowska 17; 31-016 Kraków, Poland.natalia_slaby@wp.pl

Keywords: Brachyura; Homolodromioidea; Tanidromitidae; new species; Jurassic; augenrest

Submission: 11 December 2015 Acceptance: 17 October 2016

\section{INTRODUCTION}

Jurassic family Tanidromitidae Schweitzer and Feldmann, 2008 consists of two genera; Tanidromites Schweitzer and Feldmann, 2008 and Gabriella Collins et al., 2006. As Schweitzer and Feldmann wrote in 2008, the genus Tanidromites differs from other representatives of the Prosopidae sensu lato in having a highly vaulted carapace, distinct groove pattern, and a shallow augenrest. This diagnosis was based on four species: T. insignis (von Meyer, 1860) (localities in Germany, Poland, Slovakia), $T$. etalloni (Collins in Collins and Wierzbowski, 1985) (Poland), T. sculpta (Quenstedt, 1857) (Germany, Poland) and T. richardsoni (Woodward, 1907) (Great Britain, Germany). Subsequently further species were described: T. lithuanicus Schweigert and Koppka, 2011 (Lithuania), T. maerteni Fraaije et al., 2013 (France), T. montreuilense Crônier and Boursicot, 2009 (France), T. scheffnerae Schweigert and Koppka, 2011 (Germany), T. raboeufi Robin et al., 2015 (France) and one T. pustulosa (von Meyer, 1840) was transferred into this group by Schweitzer and Feldmann (2010). The recently

http://zoobank.org/EAA411C7-C206-42F0-9262-C8CDA2BB46EC

Starzyk, Natalia. 2016. Three new species of the genus Tanidromites (Decapoda: Brachyura: Tanidromitidae) from the Late Jurassic (Oxfordian) of Poland. Palaeontologia Electronica 19.3.45A: 1-14 palaeo-electronica.org/content/2016/1660-new-species-of-tanidromites 


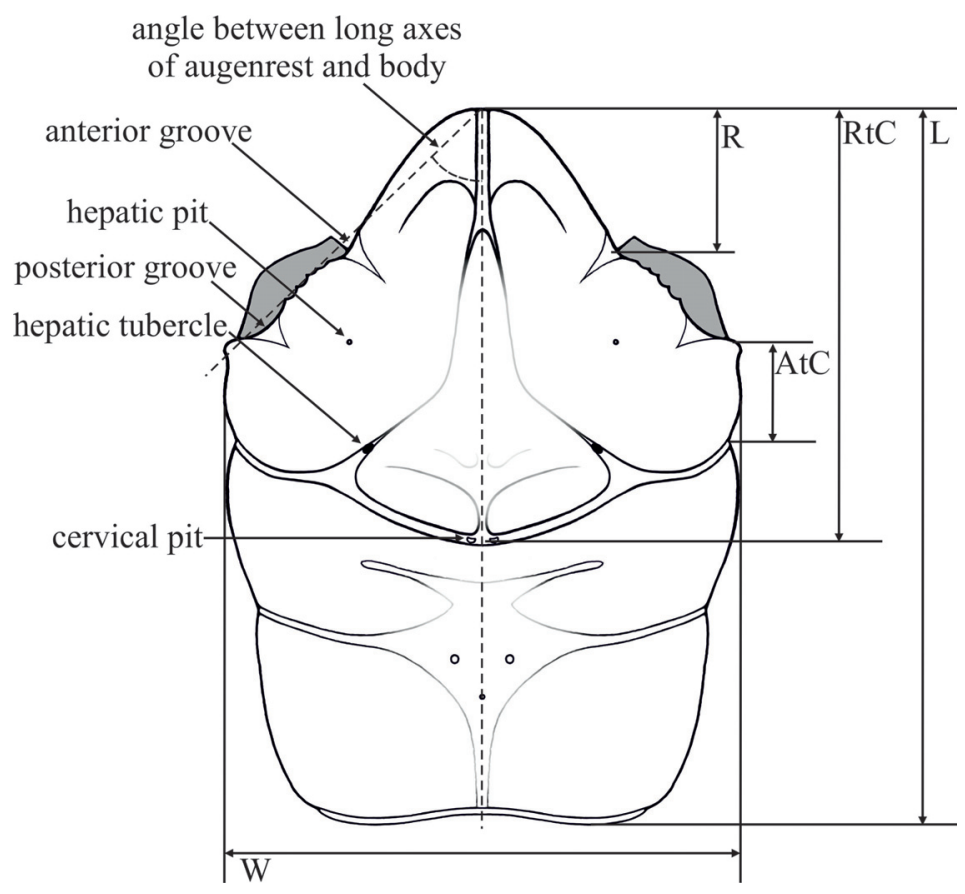

FIGURE 1. Analyzed measurements and a groundplan of the morphological structures in the species of Tanidromites on the example of $T$. alexandrae (after Starzyk, 2015a, figure 1). Further explanation in text (ag - anterior groove, hp - hepatic pit, ht - hepatic tubercle, $\mathrm{cp}$ - cervical pit). Abbreviations for the measurements are in the Material and Methods.

described Tanidromites alexandrae Starzyk (Starzyk, 2015a) diverges from the above diagnosis in having a concave augenrest. This character is present also in one of the three species described herein.

Recently also some additional structures of the carapace were described (anterior grooves, hepatic pits, hepatic tubercles - Starzyk, 2013; pseudorostral spines - Robin et al., 2015; scars on the mesogastric region - Schweitzer and Feldmann, 2009; Schweigert and Koppka, 2011); double scars on the mesogastric region - Starzyk, 2013), which supplement the diagnosis of the genus. Topology of these structures is illustrated in Starzyk (2013, figure 2) and Starzyk (2015b, figure 1).

Descriptions of new species of the genus Tanidromites are based on the specimens from the collection of Jurassic decapods housed in the Museum of the Institute of Systematics and Evolution of Animals (ISEA), Polish Academy of Sciences in Kraków, Poland (ISEA PAS, I-F/MP). The collection contains about 7,000 specimens of brachyurans (Starzyk et al., 2011, 2012; Starzyk, 2013, 2015a, 2015b) and anomurans (Fraaije et al., 2012a, 2012b, 2012c; Krzemińska et al., 2015) collected from several Oxfordian localities in the Polish Jura Chain.
There were four species previously recorded from these localities by me ( $T$. insignis, $T$. etalloni, T. sculpta, and T. scheffnerae - Starzyk, 2013) and one new species described ( $T$. alexandrae Starzyk, 2015a).

\section{MATERIAL AND METHODS}

Specimens of the three new species studied herein come from the collection of the Museum of the Institute of Systematics and Evolution of Animals, Polish Academy of Sciences in Kraków, Poland (ISEZ PAN, I-F/MP). In total, there are about 75 specimens of the species described herein determined so far. For this study the 25 best-preserved specimens were selected.

Measurements helpful for diagnostic purposes were taken from the dorsal view of the carapace. Analyzed measurements (Figure 1, Table 1) are the same as in Starzyk, 2015a except R - the length from the tip of the rostrum to the anterior groove; RtC - length from the tip of the rostrum to the cervical groove; AtC - length from the end of the outer augenrest angle (outer orbital spine if present) to the cervical groove; $\mathrm{L}$ - maximum length of the carapace; $\mathrm{W}$ - maximum width of the carapace.

The material described herein originates from five localities in the southern Polish Uplands, north- 
TABLE 1. Measurements $(\mathrm{mm})$ of 14 specimens of Tanidromites longinosa $\mathrm{n}$. $\mathrm{sp}$. and 7 specimens of Tanidromites wysokaensis $\mathrm{n}$. sp. $\mathrm{L}$ - maximum length of the carapace; $\mathrm{W}$ - maximum width of the carapace; RtC - length from the tip of the rostrum to the cervical groove; AtC - length from the end of the outer augenrest angle to the cervical groove; R length from the tip of the rostrum to the anterior groove.

\begin{tabular}{|c|c|c|c|c|c|}
\hline Specimen & $\mathbf{L}$ & $\mathbf{w}$ & RtC & AtC & $\mathbf{R}$ \\
\hline \multicolumn{6}{|c|}{ Tanidromites longinosa $\mathrm{n} . \mathrm{sp}$. } \\
\hline I-F/MP/474/1497/08 & - & - & - & 0.94 & - \\
\hline I-F/MP/530/1497/08 & 3.39 & 2.11 & 2.04 & 0.49 & 0.83 \\
\hline I-F/MP/642/1502/08 & 2.36 & 1.61 & 1.45 & 0.32 & 0.60 \\
\hline $\begin{array}{l}\text { I-F/MP/1788/1517/08 } \\
\text { paratype }\end{array}$ & 3.57 & 2.36 & 2.17 & 0.46 & 0.76 \\
\hline I-F/MP/1849/1517/08 & 2.91 & 1.86 & 1.77 & 0.39 & 0.73 \\
\hline I-F/MP/1908/1517/08 & - & - & - & 0.72 & - \\
\hline I-F/MP/2053/1517/08 & - & 3.28 & - & 0.63 & - \\
\hline I-F/MP/2054/1517/08 & 6.02 & 3.74 & 3.39 & 0.71 & 1.59 \\
\hline $\begin{array}{l}\text { I-F/MP/2725/1530/08 } \\
\text { paratype }\end{array}$ & - & - & - & 0.52 & - \\
\hline I-F/MP/6235/1588/11 & - & 8.45 & - & 1.91 & - \\
\hline I-F/MP/6238/1588/11 & - & 5.12 & - & 1.01 & - \\
\hline $\begin{array}{l}\text { I-F/MP/6239/1588/11 } \\
\text { paratype }\end{array}$ & 8.28 & 5.58 & 4.60 & 1.16 & 1.51 \\
\hline I-F/MP/6242/1588/11 & - & 6.42 & - & - & - \\
\hline $\begin{array}{l}\text { I-F/MP/6307/1599/12 } \\
\text { holotype }\end{array}$ & 4.46 & 2.94 & 2.34 & 0.58 & 0.88 \\
\hline \multicolumn{6}{|c|}{ Tanidromites wysokaensis $\mathrm{n} . \mathrm{sp}$. } \\
\hline I-F/MP/1078/1508/08 & - & 5.95 & 5.52 & 2.03 & 1.48 \\
\hline I-F/MP/1896/1517/08 & - & - & 4.13 & 1.39 & 1.23 \\
\hline I-F/MP/4507/1534/08 & - & - & - & 2.25 & - \\
\hline I-F/MP/4962/1543/09 & - & 7.18 & 6.18 & 2.15 & 1.82 \\
\hline $\begin{array}{l}\text { I-F/MP/6240/1588/11 } \\
\text { holotype }\end{array}$ & 20.34 & 12.95 & 10.88 & 4.43 & 3.08 \\
\hline $\begin{array}{l}\text { I-F/MP/6260/1588/11 } \\
\text { paratype }\end{array}$ & - & 7.37 & - & 2.74 & - \\
\hline $\begin{array}{l}\text { I-F/MP/6263/1588/11 } \\
\text { paratype }\end{array}$ & - & 14.01 & - & 4.64 & - \\
\hline \multicolumn{6}{|c|}{ Tanidromites schweitzerae n. sp. } \\
\hline $\begin{array}{l}\text { I-F/MP/4515/1534/08 } \\
\text { holotype }\end{array}$ & - & 13.92 & 12.79 & 4.26 & 3.49 \\
\hline I-F/MP/4562/1534/08 & 5.73 & 4.36 & 3.10 & 1.37 & 0.66 \\
\hline $\begin{array}{l}\text { I-F/MP/6249/1588/11 } \\
\text { paratype }\end{array}$ & - & - & 14.38 & 4.65 & 4.06 \\
\hline
\end{tabular}

west of Kraków (Poland), namely Bzów and Ogrodzieniec $\left(50^{\circ} 27^{\prime} 52^{\prime \prime} \mathrm{N} 19^{\circ} 30^{\prime} 43^{\prime \prime} \mathrm{E}\right)$, Kroczyce $\left(50^{\circ} 33^{\prime} 59^{\prime \prime} \mathrm{N} \quad 19^{\circ} 34^{\prime} 11 " \mathrm{E}\right)$, Niegowonice $\left(50^{\circ} 24^{\prime} 10^{\prime \prime} \mathrm{N} 19^{\circ} 24 ' 35 " \mathrm{E}\right)$, and Wysoka $\left(50^{\circ} 25^{\prime} 51 " \mathrm{~N}\right.$ $\left.19^{\circ} 21^{\prime} 35 " \mathrm{E}\right)$.

The localities and their stratigraphy were characterized in Fraaije et al. (2012a), where a map is provided (Fraaije et al., 2012a, figure 1). Specimens of the species studied herein and other material described before were collected by a family of amateur collectors: Iwona, Robert, and Karolina Borek. 


\section{SYSTEMATIC PALAEONTOLOGY}

Order DECAPODA Latreille, 1802

Infraorder BRACHYURA Linnaeus, 1758

Section DROMIACEA de Haan, 1833

Superfamily HOMOLODROMIOIDEA Alcock, 1900

Family TANIDROMITIDAE Schweitzer and

Feldmann, 2008

Genus TANIDROMITES Schweitzer and

Feldmann, 2008

1835 Prosopon von Meyer, p. 329 (pars).

1824 Pithonoton von Meyer, p. 71 (pars).

1861 Coelopus Étallon, p. 148 (pars).

Diagnosis (from Schweitzer and Feldmann, 2008, emended). Carapace longer than wide; width of hepatic region is $0.60-0.75$ of length, moderately to strongly vaulted transversely and longitudinally. Lateral margins parallel or converging slightly posteriorly; lateral flanks very strongly developed. Regions are distinct, usually smooth; epigastric region inflated. Protogastric and hepatic regions not differentiated. Rostrum is downturned, triangle shaped, with blunt end or with pseudorostral spines, with raised borders, divided by an axial groove. Augenrest is various, from flat to concave with differentiated shape of margins. Weak, short lateral ridge extending posteriorly from the augenrest. Angle between long axes of the augenrest and the body is 35-65. Cervical and branchio-cardiac grooves are deep (emendations in italics).

Type species. Prosopon insigne von Meyer, 1860, by original designation.

Other species included. T. alexandrae Starzyk, 2015; T. etalloni (Collins in Collins and Wierzbowski, 1985), as Coelopus; T. lithuanicus Schweigert and Koppka, 2011; T. maerteni Fraaije et al., 2013; T. montreuilense Crônier and Boursicot, 2009; T. pustulosa (von Meyer, 1840), as Pithonoton; T. raboeufi Robin et al., 2015; T. richardsoni (Woodward, 1907), as Prosopon; T. scheffnerae Schweigert and Koppka, 2011; T. sculpta (Quenstedt, 1857), as Prosopon; T. longinosa n. sp., T. wysokaensis n. sp., T. schweitzerae n. sp.

Age. The genus is known from the lower upper Bajocian to Tithonian (Fraaije et al., 2013).

Key to species of the genus Tanidromites. All the species known before and those described herein are included in the key. The nine species redescribed or described by me ( $T$. alexandrae, $T$. etalloni, T. insignis, T. lithuanicus, T. sculpta, $T$. scheffnerae, T. longinosa n. sp., T. schweitzerae $\mathrm{n}$. $\mathrm{sp}$., T. wysokaensis n. sp.) are presented in Figure 2. Other species characters are known from the lit- erature (T. maerteni - Fraaije et al., 2013, T. montreuilense - Crônier and Boursicot, 2009, T. pustulosa - Schweitzer and Feldmann, 2010, T. raboeufi - Robin et al., 2015, T. richardsoni - Schweitzer and Feldmann, 2008; Schweigert and Koppka, 2011).

1a. Outer orbital spine and anterior groove present ..........................

1b. Outer orbital spine and anterior groove absent.....................

2a. Hepatic tubercles absent [hepatic pits distinct; augenrest short, rounded; regions of carapace strongly vaulted $]. \ldots \ldots \ldots \ldots \ldots$. lithuanicus

2b. Hepatic tubercles present............... 3

3a. Hepatic pits absent [carapace slightly narrowing posteriorly; broad rostrum ] . . . . . 7T. richardsoni

3b. Hepatic pits present . . . . . . . . . . . . . 4

4a. Augenrest flat, without elevated upper and suborbital margins . ................ 5

4b. Augenrest protected by upper and suborbital margins [hepatic pits and tubercles weakly developed] . . . . . . . . . . . . . . T.exandrae

5a. Lateral borders of carapace parallel or narrowing posteriorly . . . . . . . . . . . . . . 6

5 b. Lateral borders of carapace narrowing anteriorly.............. T. montreuilense

6a. Spine on the lateral border, in front of branchiocardiac groove present [cervical groove arched backward on both sides of cervical pits] . . . . . . . . . . . . T. maerteni

6b. Spine on the lateral border in front of branchiocardiac groove absent . . . . . . . . . . . 7

7a. Distance from rostrum to end of augenrest is the smallest among all species of the genus, outer orbital spines small, blunt; carapace slightly narrowing posteriorly] . ............ T. sculpta

7b. Distance from rostrum to end of augenrest is long; augenrest short, sharply ended ......T. insignis

8a. Hepatic tubercles absent . . . . . . . . . . . . .9

8b. Hepatic tubercles present [outer orbital spines and hepatic pits absent; augenrest very short, rounded; rostrum sharply ended] ............ T. scheffnerae

9a. Augenrest longer than wide, protected by suborbital margin [hepatic pits absent, rostrum short, rounded] . ........ T. schweitzerae n. sp.

9b. Augenrest as long as wide or wider than long, flattened . . . . . . . . . . . . . . . . . . . 10

10a. Rostrum short $(\mathrm{R} / \mathrm{RtC} \leq 0.3) \ldots \ldots \ldots \ldots \ldots 11$

10b. Rostrum long $(R / R t C>0.3)$ [regions of carapace flattened; posterior part of augenrest weakly distinguished; four short spines on upper orbital margin; hepatic pits absent] ............... T. longinosa $\mathrm{n}$. sp.

11a. Rostrum rounded ...................12 


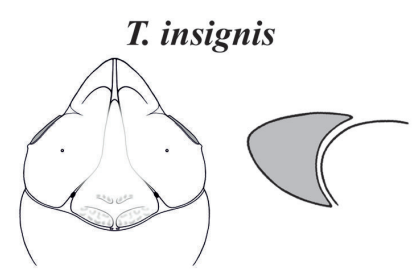

T. alexandrae

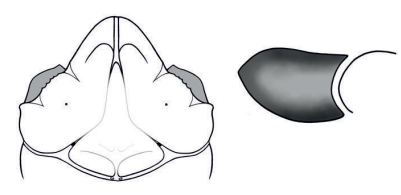

T. wysokaensis n. sp.

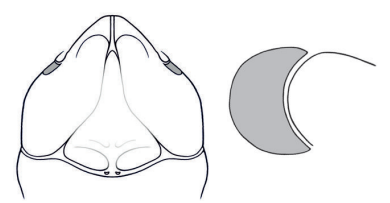

T. lithuanicus

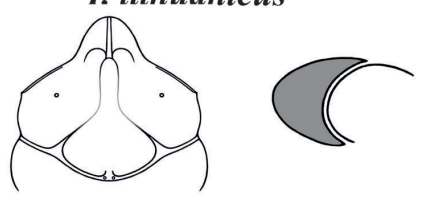

T. etalloni

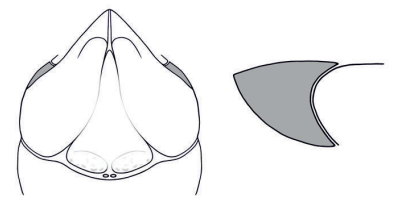

T. longinosa n. sp.

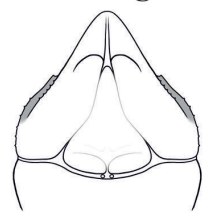

T. sculpta

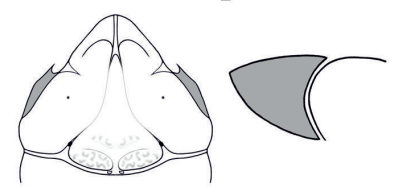

T. scheffnerae

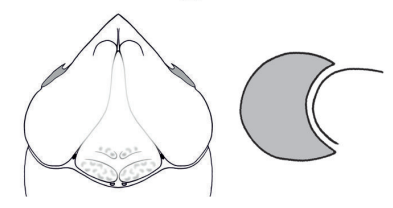

T. schweitzerae n. sp.

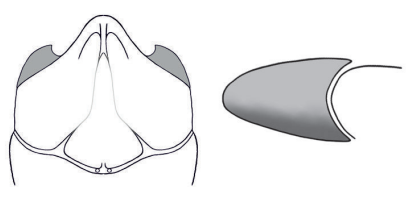

FIGURE 2. Anterior part of the carapace and the augenrest in Tanidromites spp. The area of augenrest is shaded.

11b. Rostrum sharply ended [augenrest narrowing posteriorly, sharply ended; triangular mesogastric region; anterior groove, outer orbital spine, hepatic pits absent]................. etalloni

11c. Rostrum with pseudorostral nodes [carapace convex; hepatic pits absent; augenrest rounded]. .................. raboeufi

12a. Carapace long and strongly vaulted [hepatic pits absent]............. T. wysokaensis n. sp.

12b. Carapace short [hepatic pits absent].................. T. pustulosa It is noteworthy that the abundance of a various newly described structures on the carapace allows determining the specimens even if they are only fragmentarily preserved.

\section{Tanidromites longinosa $\mathrm{n}$. sp.}

Figures 2, 3

\section{zoobank.org/8E4FDEAB-13E1-4BF7-AF53-8A47FEF1E250}

Diagnosis. Small sized species (max. carapace length $8.28 \mathrm{~mm}$ ). Carapace is widest across hepatic region. Outer orbital spine is absent. There are small spines on lateral border between augenrest and cervical groove. AtC distance (as defined in Figure 1) is short (0.21-0.25 of RtC). Rostrum is very long ( $R / R t C>0.3)$ with a blunt tip. Augenrest is as long as wide, with short spines on the upper and suborbital margin. Posterior section of orbital margin smoothly changes into lateral border of the carapace. Cervical pits are rounded. Hepatic pits and hepatic tubercles are absent.

Comparison. The species is most similar to Tanidromites sculpta. It is also a small sized species; as $T$. sculpta, T. etalloni, and $T$. alexandrae. The length of the biggest specimen of $T$. longinosa n.sp. is $8.28 \mathrm{~mm}$. The augenrest is flattened and as long as wide, as in T. etalloni and T. sculpta. The difference is visible in the posterior section of the orbital margin, which is distinct in $T$. sculpta and $T$. etalloni and smoothly changes into the lateral border of the carapace in $T$. longinosa. $\mathrm{n}$. sp. The rostrum of $T$. longinosa $\mathrm{n}$. sp. is longer than in other species of the genus, the ratio of length from the tip of the rostrum to the anterior groove, and of the length from the tip of the rostrum to the cervical groove is larger than 0.3 . Another difference is visible in the convexity of the carapace, which in $T$. longinosa $\mathrm{n}$. sp. is slightly convex, while in $T$. sculpta and $T$. alexandrae it is flat and in other species is highly convex.

Etymology. The trivial name refers to the long rostrum of this species. It comes from the Latin words longus - long, nasus - nose. 


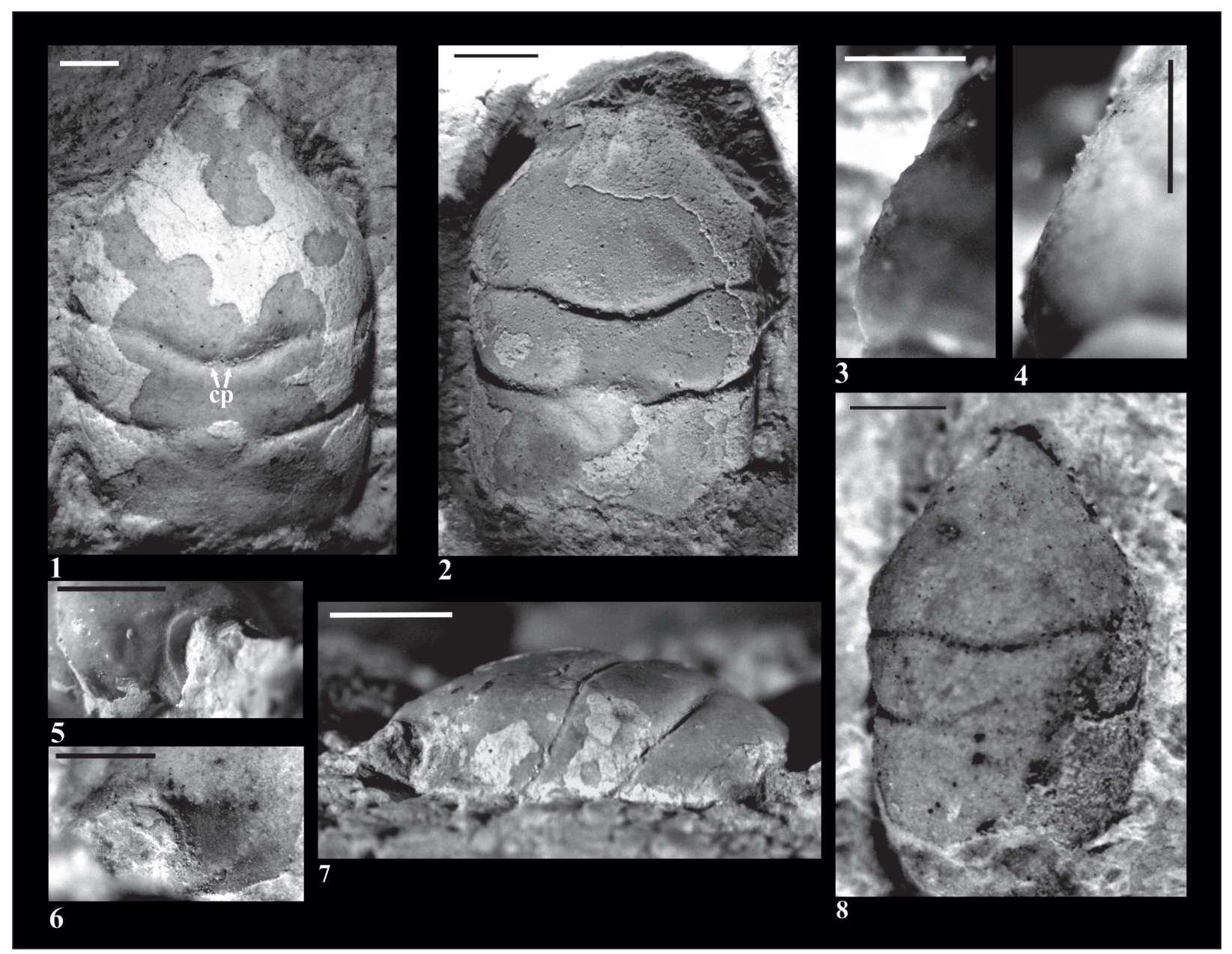

FIGURE 3. Tanidromites longinosa n. sp. 1, paratype (\#6239, Ogrodzieniec) (cp - cervical pit); 2, specimen (\#6242, Ogrodzieniec); 3, 4, upper orbital margin (3 - \#2725 Bzów; 4 - \#1908, Bzów); 5, 6, augenrest, anterior view (5 \#6302, Kroczyce; 6 -\#1908, Bzów); 7, lateral view (\#6238, Kroczyce); 8, holotype (\#6307, Ogrodzieniec). Scale bars equal $1 \mathrm{~mm}$.

\section{Material}

Type material. Holotype: I-F/MP/6307/1599/12; type locality: Ogrodzieniec; age: Early-Middle Oxfordian.

Paratypes. I-F/MP/6239/1588/11; locality: Ogrodzieniec; I-F/MP/1788/1517/08; I-F/MP/2725/ 1530/08; locality: Bzów; age: Middle Oxfordian. Coll.: I.K.R. Borek.

Additional material. Specimens from Bzów: I-F/ MP/1849/1517/08; I-F/MP/1908/1517/08; I-F/MP/ 2053/1517/08; I-F/MP/2054/1517/08. Specimens from Kroczyce: I-F/MP/6238/1588/11, I-F/MP/ 6302/1599/12. Specimens from Ogrodzieniec: I-F/ MP/474/1497/08; I-F/MP/530/1497/08; I-F/MP/642/ 1502/08; I-F/MP/6235/1588/11; I-F/MP/6242/1588/ 11. Coll.: I.K.R. Borek.

Total number of specimens. 34 .
Full list of the specimens and localities is presented in the Appendix.

Dimensions (Table 1). The length of the biggest specimen is $8.28 \mathrm{~mm}$ and the maximum width across the epibranchial region is $6.42 \mathrm{~mm}$.

Description. The carapace is slightly convex (Figure 3.7), widest across the hepatic region. Lateral borders are parallel or narrowing posteriorly, smooth without the outer orbital spine, except the border between the end of the augenrest and the cervical groove (AtC) - there are several small spines there (Figure 3.4). The AtC distance is short (0.21-0.25 of the RtC distance) (Figures 2, 3.1, 3.2, 3.8).

The rostrum is long $(\mathrm{R} / \mathrm{RtC}>0.3)$, downturned; the axial groove does not reach the blunt tip (Figure $3.1,3.8)$. 
The augenrest is as long as wide. There are short spines on the upper and suborbital margin (Figures 2, 3.3, 3.4). The suborbital margin slightly projects beyond the upper orbital margin. The posterior part of the orbital margin smoothly changes into the lateral border of the carapace (Figure 3.5, 3.6). This character is visible on every specimen with an augenrest preserved, which means it is not caused by preservation but it is a repetitive character.

Mesogastric region is distinctly bordered by grooves in the anterior and posterior part, weaker in the middle. Anterior (narrow) part of the region is a little shorter than the posterior (wide) part. Cervical pits are rounded (Figures 2, 3.1). There is an incision in the posterior margin of the mesogastric region. Mesogastric scars (corresponding to attachments of the gastric muscles) are elongated, weakly developed, positioned on both sides of this incision, and extend across the entire posterior border of the mesogastric region. Proximally they are accompanied by a parallel pair of smaller scars which are very faint.

Protogastric and hepatic regions are not differentiated. Hepatic pits and tubercles are absent.

Epigastric regions are elongated. There is a small tubercle on the urogastric region. Cardiac region is weakly divided; there are two tubercles in the anterior part and one in the posterior. Branchial region is much longer and almost as convex as the epibranchial one.

The cervical groove is deep. The branchiocardiac groove is deep in lateral parts (parallel to the cervical groove); middle part of this groove disappears (Figure 3.1, 3.2).

There is no ornamentation on the carapace. Internal mold and the cuticle are smooth (Figure $3.1,3.2,3.8)$. There is no well-preserved cuticle on the augenrest and no spines on the upper and suborbital margin covered with the cuticle.

Tanidromites wysokaensis $\mathrm{n}$. sp.

Figures 2, 4

\section{zoobank.org/42DE45DC-6D69-4447-9B02-E268EAA313EB}

Diagnosis. Species reaching relatively large size maximum carapace length $20.34 \mathrm{~mm}$. Carapace is widest across epibranchial region. AtC distance is very long (0.33-0.42 of RtC distance). Rostrum is short (R/RtC $\leq 0.3)$, downturned, with a blunt tip. Augenrest is flat, rounded and bordered; its length is half of width. Outer orbital spine is absent. Cervical pits are crescent-shaped. Hepatic pits and hepatic tubercles are absent.

Comparison. The species is most similar to Tanidromites scheffnerae and $T$. insignis; which are also large sized species. Maximum carapace length of T. wysokaensis n. sp. is $20.34 \mathrm{~mm}$, while the length of the biggest specimen of $T$. scheffnerae is $27.34 \mathrm{~mm}$ and of $T$. insignis $-22.5 \mathrm{~mm}$. The rostrum of $T$. wysokaensis $\mathrm{n}$. sp. is not sharply ended as in $T$. scheffnerae and $T$. etalloni but more similar to T. insignis. Tanidromites scheffnerae and $T$. insignis have hepatic tubercles and hepatic pits (only $T$. insignis) which are absent in $T$. wysokaensis $\mathrm{n}$. sp., as in T. etalloni. The shape of the augenrest is similar only to $T$. scheffnerae.

Etymology. The trivial name refers to one of the localities where this species was found - Wysoka (gender feminine, in Genitivum).

\section{Material}

Type material. Holotype: I-F/MP/6240/1588/11; type locality: Ogrodzieniec; age: Early-Middle Oxfordian. Coll.: I.K.R. Borek.

Paratypes. I-F/MP/6260/1588/11; locality: Ogrodzieniec; I-F/MP/6263/1588/11; locality: Niegowonice; age: Middle-Late Oxfordian. Coll.: I.K.R. Borek.

Additional material. Specimens from Bzów: I-F/ MP/1896/1517/08. From Niegowonice: I-F/MP/ 1078/1508/08; I-F/MP/4507/1534/08; I-F/MP/4962/ 1543/09. Coll.: I.K.R. Borek.

Total number of specimens. 18.

Full list of the specimens and localities is presented in the Appendix.

Dimensions. The width across the epibranchial region ranges between 5.95 and $12.95 \mathrm{~mm}$. The maximum carapace length $20.34 \mathrm{~mm}$.

Description. The carapace is about $1.7 x$ as long as wide, slightly convex (Figure 4.1-3, 4.5), with parallel borders. Lateral borders are smooth without the outer orbital spine. The AtC distance is very long (0.33-0.42 of the RtC) (Figures 2, 4.1-3).

The rostrum is short (R/RtC $\leq 0.3)$, downturned, with blunt tip. The axial groove reaches the anterior end of the rostrum (Figure 4.2, 4.8).

The augenrest is flat, rounded, and very short; its length is $0.5 x$ the width (Figure 2), bordered. The outer orbital spine is absent. Upper and suborbital margins are smooth (Figure 4.6, 4.7).

The mesogastric region is distinctly borderd by grooves in the anterior and posterior part, weaker in the middle. Anterior (narrow) and posterior (wide) part of the mesogastric region are more or less the same length; there is an incision in the posterior margin. Cervical pits are crescent-shaped (Figure 2). Mesogastric scars are elongated, strongly developed, positioned on both sides of the posterior incision, and extend across the entire posterior border of the mesogastric region. Proxi- 


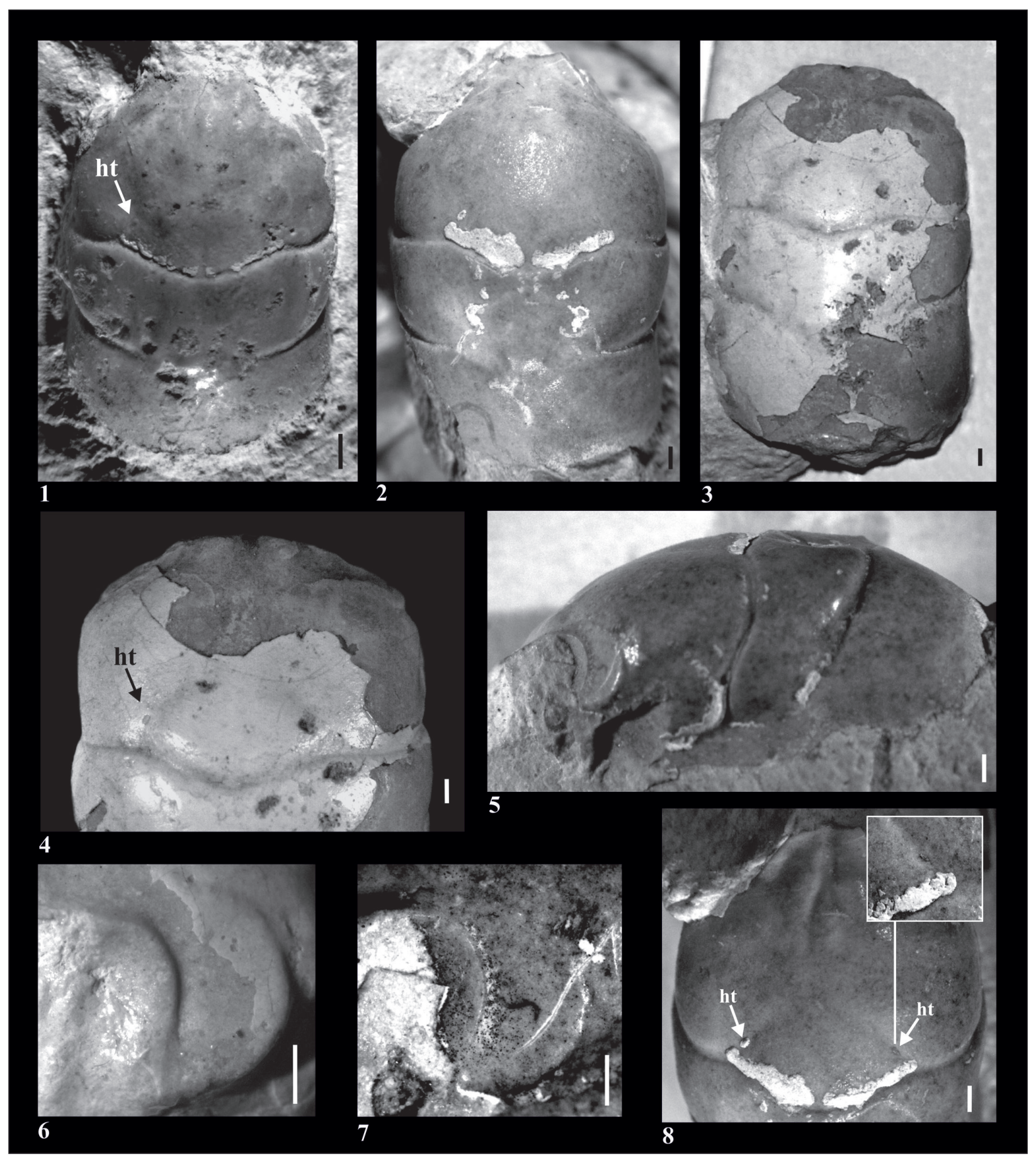

FIGURE 4. Tanidromites wysokaensis n. sp. 1, paratype (\#6260, Ogrodzieniec); 2, holotype (\#6240, Ogrodzieniec); 3, paratype (\#6263, Niegowonice); 4, anterior part of the carapace (paratype, \#6263, Niegowonice); 5, lateral view (\#6240, Ogrodzieniec); 6, 7, augenrest, anterior view (6 - \#6263, Niegowonice; 7 - \#6240, Ogrodzieniec); 8, anterior part of the carapace (holotype, \#6240, Ogrodzieniec). ht - hepatic tubercle. Scale bars equal $1 \mathrm{~mm}$.

mally they are accompanied by a parallel pair of smaller scars. Protogastric and hepatic regions are not differentiated. Hepatic pits and hepatic tubercles are absent.
Epigastric regions are elongated. There is a small tubercle on the urogastric region.

There are two tubercles lying on the anterior part of the cardiac region. The posterior tubercle is absent. 


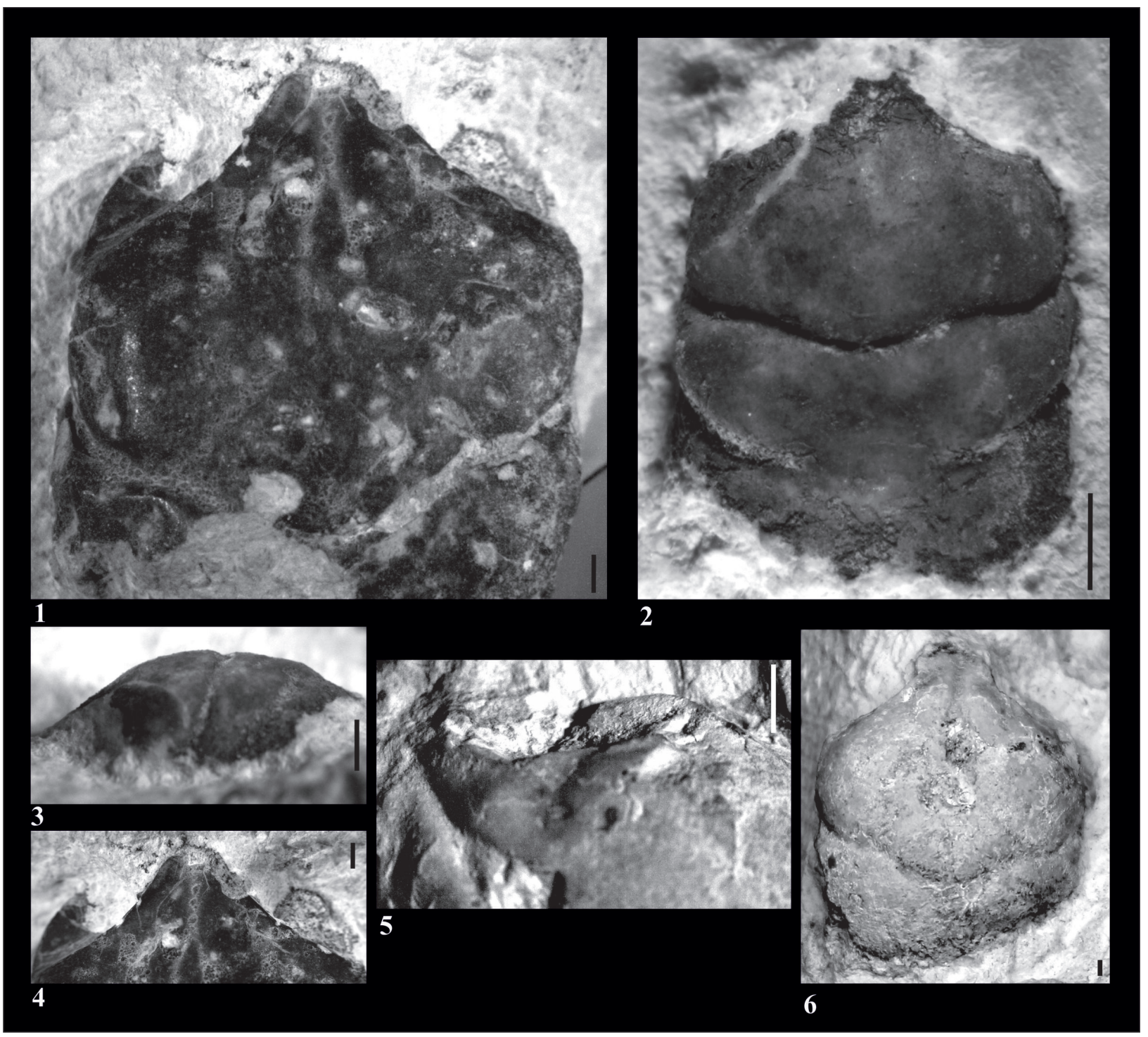

FIGURE 5. Tanidromites schweitzerae n. sp. 1, holotype (\#4515, Niegowonice); 2, specimen (\#4562, Niegownice); 3, lateral view (\#4562, Niegowonice); 4, rostrum (holotype \#4515, Niegowonice); 5, augenrest, view from above (holotype \#4515, Niegowonice); 6, specimen (\#6249, Niegowonice). Scale bars equal $1 \mathrm{~mm}$.

The epibranchial region is strongly convex, branchial region more flattened. The epibranchial region is much shorter than branchial and hepatic regions.

The cervical groove is deep. The branchiocardiac groove is deep on the lateral sides (parallel to the cervical groove), the middle part is very weakly visible. The posterior border of the carapace is broad and strongly concave in the middle part. It is rimmed.

There is no ornamentation on the carapace. Internal mold and the cuticle are smooth. A cuticle is preserved on the hepatic tubercles of the paratype (\#6263, Figure 4.4) and on one hepatic tuber- cle of the holotype (\#6240, Figure 4.8). They are distinct in both cases, with and without the cuticle.

Tanidromites schweitzerae $\mathrm{n}$. sp.

Figures 2, 5

zoobank.org/52BB1CE6-3303-4980-BE15-ECA9B86D3521

Diagnosis. Species reaching relatively large size maximum carapace width is $14.75 \mathrm{~mm}$. Carapace is flattened, with parallel lateral borders. AtC distance is very long (0.33-0.44 of RtC distance). Rostrum is short (R/RtC $\leq 0.3)$ with a blunt tip. Augenrest is long (length is $0.75 \mathrm{x}$ width), protected only by suborbital margin, which extends beyond upper orbital margin and is strongest among all 
TABLE 2. All species of the genus Tanidromites with their respective habitats (information from Crônier and Boursicot, 2009; Fraaije et al., 2013; Hyžný et al., 2011; Müller et al., 2000; Robin et al., 2015; Schweigert and Koppka, 2011; Schweitzer and Feldmann, 2010; Starzyk, 2015a).

\begin{tabular}{|c|c|c|}
\hline Species & Age & Habitat \\
\hline T. sculpta & $\begin{array}{l}\text { Early Oxfordian to Late } \\
\text { Kimmeridgian }\end{array}$ & shallow sponge- microbial mounds \\
\hline T. scheffnerae & $\begin{array}{l}\text { Early Oxfordian to Late } \\
\text { Kimmeridgian }\end{array}$ & shallow sponge- microbial mounds (Poland, Germany) \\
\hline T. etalloni & Middle to Late Oxfordian & shallow sponge- microbial mounds (Poland) \\
\hline T. alexandrae & Early to Late Oxfordian & shallow sponge- microbial mounds (Poland) \\
\hline T. insignis & $\begin{array}{l}\text { Early Oxfordian to Early } \\
\text { Kimmeridgian }\end{array}$ & $\begin{array}{l}\text { non reefal habitat associated fauna sparse; brachiopods, } \\
\text { bivalves and crinoids (Slovakia) shallow sponge- microbial } \\
\text { mounds (Poland, Germany) }\end{array}$ \\
\hline T. lithuanicus & Middle Callovian & $\begin{array}{l}\text { shallow non reefal habitats associated with benthic } \\
\text { macrofauna (Lithuania) }\end{array}$ \\
\hline T. montreuilense & Early Callovian & $\begin{array}{l}\text { lower offshore environment, close to or below storm wave } \\
\text { base, with water depth } 50-80 \mathrm{~m} \text {, associated with benthic } \\
\text { fauna (France) }\end{array}$ \\
\hline T. raboeufi & Late Bathonian & carbonate muddy buttoms (France) \\
\hline T. richardsoni & Bajocian & $\begin{array}{l}\text { shallow non reefal habitats associated with benthic } \\
\text { macrofauna (Great Britain, Germany) }\end{array}$ \\
\hline T. maerteni & Early Bajocian & shallow non reefal habitats associated (France) \\
\hline
\end{tabular}

species of the genus. Cervical pits are rounded. Hepatic pores and hepatic tubercles are absent. Comparison. Tanidromites schweitzerae differs from other species of Tanidromites significantly. It has a unique shape of the augenrest, long with an extended suborbital margin. The rostrum is also different, short $(\mathrm{R} / \mathrm{RtC} \leq 0.3)$ with a blunt tip. Epibranchial regions are strongly elongated, not round as in other species of the genus.

Etymology. The trivial name is dedicated to Carrie E. Schweitzer, an outstanding specialist of fossil decapods.

\section{Material}

Type material. Holotype: I-F/MP/4515/1534/08; type locality: Niegowonice; age: Middle-Late Oxfordian. Coll.: I.K.R. Borek.

Paratype. I-F/MP/6249/1588/11; locality: Niegowonice. Coll.: I.K.R. Borek.

Additional material. Specimen from Niegowonice: I-F/MP/4562/1534/08. Coll.: I.K.R. Borek.

Total number of specimens. 3 .

Dimensions. Maximal width across the epibranchial region is $14.75 \mathrm{~mm}$.

Description. The carapace is flattened (Figure 5.5). Lateral borders are smooth and parallel. The AtC distance is very long (0.33-0.44 of the RtC ) (Figures 2, 5.1, 5.6, 5.7).

The rostrum is short $(\mathrm{R} / \mathrm{RtC} \leq 0.3)$ with a blunt tip. The axial groove is shallow; it does not reach the anterior border of the rostrum. The rostrum is best visible on the specimen 4515 (Figure 5.1, 5.2). The augenrest is long (length is about 0.75 of the width) (Figures 2, 5.2-4). Upper and suborbital margins are smooth without any spines or incisions. The suborbital margin is extending beyond the upper orbital margin, strongest of all the species of the genus. The anterior groove is not visible.

The mesogastric region is distinctly bordered by grooves in the anterior and posterior part, weaker in the middle. The anterior (narrow) and posterior (wide) part of the region are more or less the same length. There is an incision in the posterior margin of this region. Cervical pits are rounded. Mesogastric scars are elongated, strongly developed, positioned on both sides of this incision, and extend across the entire posterior border of the mesogastric region. Proximally they are accompanied by a parallel pair of smaller scars which are very weakly visible.

Protogastric and hepatic regions are not differentiated. Hepatic pits and hepatic tubercles are absent. Epigastric regions are strongly elongated. The tubercle on the urogastric region is absent.

The cardiac region is weakly preserved only on specimen 4562. There are two tubercles in the anterior part and one in the posterior part.

The epibranchial region is more convex, and branchial region more flattened. The epibranchial 
region is much shorter than branchial and hepatic regions.

The cervical groove is deep. The branchiocardiac groove is deep on the lateral sides (parallel to the cervical groove), the middle part is more shallow but also distinct.

There is no ornamentation on the carapace. The cuticle is not preserved on any of the speimens.

\section{DISCUSSION}

Recently Tanidromites insignis was discovered in non-reefal/biohermal deposits aged as Middle Oxfordian (Hyžný et al., 2011). This finding confirms a wide spectrum of adaptations of the genus Tanidromites representatives to different types of environments (Table 2). This diversity is reflected in morphologic features and also in size differences.

As Klompmaker and others (2013a) wrote, reef expansion could be the cause of decapods diversification. The stratigraphically oldest species of Tanidromites are known from the Middle Jurassic (T. maerteni, T. richardsoni, T. raboeufi - Upper Bajocian). In this period reefal environments were rare (Müller et al., 2000, Krobicki and Zatoń, 2008, Kiessling, 2009). Scarcity of reefs might be the reason of a small number of crab species discovered from this period (Klompmaker et al., 2013a, 2013b). Middle Jurassic species lived in shallow or moderately deep waters near the coast (Crônier and Boursicot, 2009). Deep augenrest was not a common character. The eyestalks of the Middle Jurassic species were not protected; their augenrest was a flat surface. It could be plausibly related to lack of need to protect the eye from injuries.

More favorable conditions appeared in connection with a transgression in the Callovian, when sponge reefs started to spread more frequently. A large number of tanidromitids and other crabs described from the Late Jurassic demonstrates how beneficial reefal environments for crabs were. These animals could use reefs as shelters, they were also rich in nutrition, and could also be kind of nutrition themselves (Klompmaker et al., 2013a; Krobicki and Zatoń, 2008). Appearing of deep augenrest might be caused by need to protect the eye from the damage from reef skeletons. In the Late Jurassic most of the tanidromitid species still had flattened augenrests: $T$. insignis, $T$. sculpta, $T$. etalloni, T. scheffnerae, T. pustulosa, and T. wysokaensis n. sp. However, some of the species apparently developed a protection for the eyestalks in the form of an extension of the suborbital margin, and in some of them also of the upper orbital margin. In $T$. longinosa $\mathrm{n}$. sp. the suborbital margin is a little curved, and the upper and suborbital margins are covered with small spines. The posterior part of the orbital margin smoothly changes into the lateral border of the carapace; it is not distinct as in other species of Tanidromites. This character is visible on every specimen with an augenrest preserved. This means it is not caused by preservation but it is a repetitive character. Changes of the augenrest shape in $T$. schweitzerae n. sp. and $T$. alexandrae are much more conspicuous. In T. schweitzerae $\mathrm{n}$. $\mathrm{sp}$. the eyestalk was protected from below by very strongly projected suborbital margin. The upper orbital margin was not modified in any way. In $T$. alexandrae the eyestalk was retracted between the enlarged upper and suborbital margins (Starzyk, 2015a). Both these species had a long augenrest while other species had it short and flattened. Probably the enhanced protection enabled to develop a longer eyestalk. The more exposed eye could be advantageous in more open habitats. Similar observation was previously made on the species of Goniodromites (Starzyk et al., 2012). Many other Late Jurassic crabs had deep augenrest, ex. representatives of all Jurassic goniodromitid genera (Schweitzer and Feldmann, 2008; Starzyk et al., 2012; Starzyk, 2015a). Species of the genus Bucculentum developed different adaptation; their augenrest is situated on the dorsal surface of the carapace (Schweitzer and Feldmann, 2009; Starzyk et al., 2011).

Also a size (Table 1) and shape of the crab's body seem to be related with the type of the environment. Small size of the carapace of Jurassic crabs and their reduced abdomen were great adaptations to expanding reefs. Crabs could colonize many niches in sponge reefs and hide from predators. These niches were not available for larger animals (Förster, 1985; Klompmaker et al., 2015).

The diversity of forms suggests a complex ecology with many modes of life. Sponge and coral reefs opened many opportunities for them.

Despite these substantial differences, a close relationship of all the species of Tanidromites is evident. Species with deep augenrest share other features of the genus with those with shallow augenrest. Except characters mentioned above these are features distinguishing species of the genus described previously (Starzyk, 2013): presence of anterior grooves, presence and size of 
hepatic pits, presence and appearance of hepatic tubercles, shape of cervical pits.

\section{ACKNOWLEDGEMENTS}

I would like to thank E. Krzemińska for her critical reading of the manuscript. I am very grateful to J. Koppka for taking the photographs of the Tanidromites lithuanicus holotype. I also thank the reviewers: C.E. Schweitzer and A.A. Klompmaker for their work and helpful leads. This project was supported by the grant No. N N303 811940 of the Polish Ministry of Science and Education to $\mathrm{N}$. Starzyk and E. Krzemińska.

\section{REFERENCES}

Alcock, A. 1900. Materials for a carcinological fauna of India. No. 5. The Brachyura Primigenia, or Dromiacea. Journal of the Asiatic Society of Bengal, 68(2):123-169.

Collins, J.S.H. and Wierzbowski, A. 1985. Crabs from the Oxfordian sponge megafacies of Poland. Acta Geologica Polonica, 35(1-2):73-88.

Collins, J.S.H., Ross, A.J., Genzano, G., and Manzian, H. 2006. Earleria gen. nov. and Gabriella gen. nov., replacement names for Foersteria Arai and Brinkmann-Voss, 1980 (Cnidaria, Hydrozoa, Mitrocomidae) and Foersteria Wehner, 1988 (Crustacea, Decapoda, Prosopidae), junior homonyms of Foersteria Szépligeti, 1896 (Insecta, Hymenoptera, Braconidae). Bulletin of the Mizunami Fossil Museum, 33:125-126.

Crônier, C. and Boursicot, P.Y. 2009. A new decapod crustacean faunule from the Middle Jurassic of northwest France. Palaeontology, 52(6):1275-1289.

de Haan, W. 1833-1850. Crustacea, p. 1-243. In de Siebold, P.F. (ed.), Fauna Japonica sive Descriptio Animalium, quae in Itinere per Japoniam, Jussu et Auspiciis Superiorum, qui Summum in India Batava Imperium Tenent, Suscepto, Annis 1823 - 1830 Collegit, Notis, Observationibus et Adumbrationibus Illustravit. J. Müller et Co., Lugduni-Batavorum (=Leiden).

Étallon, A. 1861. Notes sur les Crustacés Jurassiques du bassin du Jura. Mémoires de la Societé de l'Agriculture, des Sciences et Lettres de la Haute Saône, 9:129-171.

Förster, R. 1985. Evolutionary trends and ecology of Mesozoic decapod crustaceans. Transactions of the Royal Society of Edinburgh, 76:299-304.

Fraaije, R.H.B., Krzemiński, W., van Bakel, B.W.M., Krzemińska, E., and Jagt, J.W.M. 2012a. The earliest record of pylochelid hermit crabs from the Late Jurassic of southern Poland, with notes on paguroid carapace terminology. Acta Palaeontologica Polonica, 57:647-654.
Fraaije, R.H.B., Krzemiński, W., van Bakel, B.W.M., Krzemińska, E., and Jagt, J.W.M. 2012b. New Late Jurassic symmetrical hermit crabs from the southern Polish Uplands and early paguroid diversification. Acta Palaeontologica Polonica 57:647-654. dx.doi.org/10.4202/app.2012.0022

Fraaije, R.H.B., Krzemiński, W., van Bakel, B.W.M., Krzemińska, E., and Jagt, J.W.M. 2012c. The sixth abdominal tergites of paguroid anomurans - a newly recognized crustacean macrofossil type. Neues Jahrbuch für Geologie und Paläontologie, Abhandlungen, 266:115-122.

Fraaije, R.H.B., van Bakel, B.W.M., Guinot, D., and Jagt, J.W.M. 2013. A new Middle Jurassic (Bajocjan) homolodromioid crab from northwest France; the earliest record of the Tanidromitidae. Boletín de la Sociedad Geológica Mexicana, 65(2):249-254.

Hyžný, M., Schlögl, J., and Krobicki, M. 2011. Tanidromites insignis (von Meyer, 1857) (Crustacea: Decapoda: Brachyura) from Late Jurassic non-biohermal facies of the Western Tethys (Pieniny Klippen Belt, Western Carpathians, Slovakia). Neues Jahrbuch für Geologie und Paläontologie - Abhandlungen, 262:213-226.

Kiessling, W. 2009. Geologic and biologic control on the evolution of reefs. Annual Review of Ecology, Evolution, and Systematics, 40:173-92.

Klompmaker, A.A., Ortiz, J.D., and Wells, N.A. 2013b. How to explain a decapod crustacean diversity hotspot in a mid-Cretaceous coral reef. Palaeogeography, Palaeoclimatology, Palaeoecology, 374:256273.

Klompmaker, A.A., Schweitzer, C.E., Feldmann, R.M., and Kowalewski, M. 2013a. The influence of reefs on the rise of Mesozoic marine crustaceans. Geology, 41(11):1179-1182.

Klompmaker, A.A., Schweitzer, C.E., Feldmann, R.M., and Kowalewski, M. 2015. Environmental and scaledependent evolutionary trends in the body size of crustaceans. Proceedings of the Royal Society B: Biological Sciences, 282:20150440.

Krobicki, M. and Zatoń, M. 2008. Middle and Late Jurassic roots of brachyuran crabs: Palaeoenvironmental distribution during their early evolution. Palaeogeography, Palaeoclimatology, Palaeoecology, 263:30-43.

Krzemińska, E., Krzemiński, W., Fraaije, R.H.B., van Bakel, B.W.M., and Jagt, J.W.M. 2015. Allometric ontogenetic changes in two Late Jurassic gastrodorid hermit crabs (Crustacea, Decapoda, Anomura) from central Europe. Journal of Systematic Palaeontology, 14(2):1-10. dx.doi.org/10.1080/14772019.2015.1018968

Latreille, P.A. 1802-1803. Histoire naturelle, générale et particulière, des crustacés et des insectes. F. Dufart, Paris.

Linnaeus, C.V. 1758. Systema naturae per regna tria naturae, secundum classes, ordines, genera, species, cum characteribus, differentiis, synonymis, locis (edition 10). Volume 1. Stockholm (Laurentii Slavii). 
Müller, P., Krobicki, M., and Wehner, G. 2000. Jurassic and Cretaceous primitive crabs of the family Prosopidae (Decapoda: Brachyura) - their taxonomy, ecology and biogeography. Annales Societalis Poloniae, 70:49-79.

Quenstedt, F.A. 1856-1858. Der Jura. Verlag der H. Lauppschen Buchhaldung, Tübingen.

Robin, N., van Bakel, B.W.M., d'Hondt, J.-L., and Charbonnier, S. 2015. A new early brachyuran (Crustacea, Decapoda) from the Middle Jurassic of northwest France, epibionts and ecological considerations. Contributions to Zoology, 84(3):179-191.

Schweigert, G. and Koppka, J. 2011. Decapods (Crustacea: Brachyura) from the Jurassic of Germany and Lithuania, with descriptions of new species of Planoprosopon and Tanidromites. Neues Jahrbuch für Geologie und Paläontologie - Abhandlungen, 260(2):203-210.

Schweitzer, C.E. and Feldmann, R.M. 2008. A new Classification for some Jurassic Brachyura (Crustacea: Decapoda: Brachyura: Homolodromioidea): Families Goniodromitidae Beurlen, 1932 and Tanidromitidae new family. Senckenbergiana lethaea, 87(2):119156.

Schweitzer, C.E. and Feldmann, R.M. 2009. Revision of the Prosopinae sensu Glaessner, 1969 (Crustacea: Decapoda: Brachyura) including four new families, four new genera, and five new species. Annalen des Naturhistorischen Museums in Wien, 110A:55-121.

Schweitzer, C.E. and Feldmann, R.M. 2010. The genus Coelopus Étallon, 1861 (Brachyura: Glaessneropsoidea: Longodromitidae) with new species. Neues Jahrbuch für Geologie und Paläontologie - Abhandlungen, 258:51-60.

Starzyk, N., Krzemińska, E., and Krzemiński, W. 2011. Intraspecific variation in the Jurassic crab Bucculentum bucculentum (Decapoda: Homolodromioidea:
Bucculentidae). Neues Jahrbuch für Geologie und Paleontologie - Abhandlungen, 260(2):203-210.

Starzyk, N., Krzemińska, E., and Krzemiński, W. 2012. A new crab species from the Oxfordian of Poland (Decapoda: Brachyura: Goniodromitidae). Neues Jahrbuch für Geologie und Paläontologie, Abhandlungen, 263(2):143-153.

Starzyk, N. 2013. Jurassic crabs: new characters of carapace diagnostic to known tanidromitid species. Neues Jahrbuch für Geologie und Paläontologie Abhaldungen, 269(2):173-187.

Starzyk, N. 2015a. New species of the genus Tanidromites (Decapoda: Brachyura: Tanidromitidae) from the Oxfordian of Poland. Acta zoologica cracoviensia, 58(2):129-136.

Starzyk, N. 2015b. Reappraisal of the primitive crab Eodromites, with description of three new species from European localities (Decapoda: Brachyura: Goniodromitidae). Palaeontologia Electronica 18.3.50A: $1-19$ palaeo-electronica.org/content/2015/1345-the-crabeodromites

von Meyer, H. 1835. Briefliche Mitteilungen. Neues Jahrbuch für Mineralogie, Geognosie, Geologie und Petrefakten-Kunde, Stuttgart (E. Schweizerbart), 1329.

von Meyer, H. 1840. Neue Gattungen fossiler Krebse aus Gebilden vom bunten Sandsteine bis in die Kreide. Stuttgart (E. Schweizerbart), 1-23.

von Meyer, H. 1842. Über die in dem dichten Jurakalk von Aalen in Württemberg vorkommend Spezies des Crustaceengenus Prosopon. Beiträge zur Petrefactenkunde, 5:70-75.

von Meyer, H. 1860. Die Prosoponiden oder die Familie der Maskenkrebse. Palaeontographica, 7:183-222.

Woodward, H. 1907. On a new brachyurous Crustacean from the 'Clypeus-Grit' (Inf. Oolite) of the Cotteswold Hills. Geological Magazine, new series, 4:79-81. 


\section{APPENDIX}

Specimens of Tanidromites longinosa $\mathrm{n}$. sp. and Tanidromites wysokaensis $\mathrm{n}$. $\mathrm{sp}$. in the Museum of the Institute of Systematics and Evolution of Animals, Polish Academy of Sciences in Kraków. Specimens of Tanidromites longinosa $\mathrm{n}$. $\mathrm{sp}$. in the Museum of the Institute of Systematics and Evolution of Animals, Polish Academy of Sciences in Kraków:

Specimens from Bzów: I-F/MP/1282/1508/08; I-F/ MP/1788/1517/08; I-F/MP/1849/1517/08; I-F/MP/ 1908/1517/08; I-F/MP/2053/1517/08; I-F/MP/2054/ 1517/08; I-F/MP/2134/1517/08; I-F/MP/2158/1517/ 08; I-F/MP/2376/1528/08; I-F/MP/2535/1528/08; IF/MP/2613/1528/08; I-F/MP/2725/1530/08.

Specimens from Kostkowice: I-F/MP/5848/1555/ 09.

Specimens from Kroczyce: I-F/MP/6238/1588/11; IF/MP/6302/1599/12.

Specimens from Niegowonice: I-F/MP/819/1507/ 08; I-F/MP/5643/1543/09; I-F/MP/6053/1555/09.

Specimens from Ogrodzieniec: I-F/MP/36/1489/08; I-F/MP/67/1489/08; I-F/MP/474/1497/08; I-F/MP/
500/1489/08; I-F/MP/503/1497/08; I-F/MP/530/ 1497/08; I-F/MP/603/1502/08; I-F/MP/642/1502/ 08; I-F/MP/4178/1534/08; I-F/MP/4203/1534/08; IF/MP/4404/1534/08; I-F/MP/5990/1543/09; I-F/MP/ 6235/1588/11; I-F/MP/6239/1588/11; I-F/MP/6242/ 1588/11; I-F/MP/6307/1599/12.

Specimens of Tanidromites wysokaensis n. sp. in the Museum of the Institute of Systematics and Evolution of Animals, Polish Academy of Sciences in Kraków:

Specimens from Bzów: I-F/MP/1896/1517/08; I-F/ MP/3889/1532/08.

Specimens from Niegowonice: I-F/MP/318/1497/ 08; I-F/MP/1078/1508/08; I-F/MP/1118/1508/08; IF/MP/1156/1508/08; I-F/MP/3290/1532/08; I-F/MP/ 4507/1534/08; I-F/MP/4621/1534/08; I-F/MP/4962/ 1543/09; I-F/MP/5326/1543/09; I-F/MP/6043/1555/ 09; I-F/MP/6263/1588/11.

Specimens from Ogrodzieniec: I-F/MP/6240/1588/ 11; I-F/MP/6260/1588/11.

Specimens from Wysoka: I-F/MP/2748/1530/08; IF/MP/6377/1619/14. 